\title{
Heat shock protein 90 regulates IkB kinase complex and NF-kB activation in angiotensin II-induced cardiac cell hypertrophy
}

\author{
Kyung Hye Lee ${ }^{1,2,3}$, Yangsoo Jang ${ }^{1,2,3,4}$ \\ and Ji Hyung Chung ${ }^{1,2,3,4,5}$ \\ ${ }^{1}$ Severance Integrative Research Institute \\ for Cerebral and Cardiovascular Diseases \\ Yonsei University Health System \\ Seoul 120-752, Korea \\ ${ }^{2}$ Cardiovascular Research Institute \\ Yonsei University College of Medicine \\ Seoul 120-752, Korea \\ ${ }^{3}$ Yonsei University Research Institute of Science for Aging \\ Yonsei University \\ Seoul 120-749, Korea \\ ${ }^{4}$ Severance Medical Research Institute \\ Yonsei University Health System \\ Seoul 120-752, Korea \\ ${ }^{5}$ Corresponding author: Tel, 82-2-2228-0374; \\ Fax, 82-2-2227-7869; E-mail, jhchung@yonsei.ac.kr \\ DOI 10.3858/emm.2010.42.10.069
}

Accepted 24 August 2010

Available Online 24 August 2010

Abbreviations: 17-AAG, 17-allylaminogeldanamycin; ANF, artrial natriuretic factor; Ang II, angiotensin II; AT1R, angiotensin II type 1 receptor; AT2R, angiotensin II type 2 receptor; CT-1, cardiotrophin-1; GA, geldanamycin; HSF1, heat shock factor 1; HSP, heat shock protein; IKK, IKB kinase

\footnotetext{
Abstract

Heat shock protein 90 (HSP90), one of the most abundant proteins in the cardiac cells is essential for cell survival. Previous studies have shown that angiotensin II induces cardiac cell hypertrophy. However, the role of HSP9O in the angiotensin Il-induced cardiac hypertrophy is unclear. In this study, we showed that HSP9O regulated angiotensin II-induced hypertrophy via maintenance of the IKB kinase (IKK) complex stability in cardiac cells. An HSP90 inhibitor, geldanamycin (GA), significantly suppressed angiotensin Il-induced $\left[^{3} \mathrm{H}\right]$ leucine incorporation and atrial natriuretic factor expression in cardiac cells. GA also inhibited the NF- $\mathrm{kB}$ activation induced by angiotensin II. Importantly, treatment with GA caused a degradation of $\mathrm{IKK} \alpha / \beta$; on the other hand, a proteasome-specific in-
}

hibitor restored the level of IKK $\alpha / \beta$. We also found that GA prevented HSP90-IKKs complex induced by angiotensin II in cardiac cells. The small interfering RNA (siRNA)-mediated knockdown of HSP90 expression significantly inhibited angiotensin II-induced cell hypertrophy and NF-KB activation. These results suggest that angiotensin II-induced cardiac hypertrophy requires HSP9O that regulates the stability and complex of IKK.

Keywords: angiotensin II; cardiomyopathy, hypertrophic; geldanamycin; HSP90 heat-shock proteins;

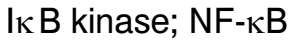

\section{Introduction}

Cardiac hypertrophy is an increase in the size of cardiac myocytes to generate greater muscle mass, usually driven by a larger workload for the heart (Heineke et al., 2006). Although it is an adaptive response to physical exercise, excessive hypertrophy can result in arrhythmia, dilated cardiomyopathy, fibrotic disease, heart failure, and sudden death (Marian and Roberts, 1995). Cardiac hypertrophy is induced by various vasoactive peptides, cytokines, and several neurohormones such as epinephrine, norepinephrine, and aldosterone (Frey and Olson, 2003). Angiotensin II, a vasoactive octapeptide, is an important humoral factor responsible for cardiac hypertrophy (Kim and Iwao, 2000). Numerous studies have shown that angiotensin II induces nuclear factor- $\kappa \mathrm{B}(\mathrm{NF}-\kappa \mathrm{B})$ activation in cultured cardiac cells (Brasier et al., 2000; Kim and Iwao, 2000) and reported that the activation of $\mathrm{NF}-\kappa \mathrm{B}$ is required for hypertrophic responses from primary rat neonatal ventricular cardiomyocytes (Purcell et al., 2001; Li et al., 2004). NF-kB is a ubiquitously expressed cytoplasmic transcription factor whose primary mode of regulation is through nuclear translocation. The most abundant form of NF- $\kappa \mathrm{B}$ transcription factor is heterodimer of p65 and p50 in several family members (Pereira and Oakley, 2008). The NF-кB p65 subunit is sequestered in the cytoplasm by interaction with the inhibitor of $\kappa B(I \kappa B)$. If cells are stimulated by several factors, phosphorylation of $I_{\kappa} B \alpha$ leads to its ubiquitination and degradation, 
permitting NF- $\alpha \mathrm{B}$ to translocate to the nucleus (Pereira and Oakley, 2008). One of the best-known pathways of $1 \kappa \mathrm{B} \alpha$ phosphorylation is activation of $I_{\kappa} B$ kinase $(\mathrm{IKK})$ complex, which is composed of $\mathrm{IKK} \alpha / \beta$ and $\mathrm{IKK} \gamma$, and these possess essential kinase activity to phosphorylate $\mathrm{I}_{\kappa} \mathrm{B}$ (Luo et al., 2005).

Recent studies have demonstrated that heat shock proteins (HSPs) are involved in cardiac hypertrophy induced by a wide variety of stimuli. The cardiotrophin-1 (CT-1), an interleukin-6 family cytokine causes an increase of HSP56 expression leading to cellular hypertrophy in cardiac myocytes (Railson et al., 2001). HSP27 regulates the change of muscle mass induced by mechanical load in rat hind limb models (Kawano et al., 2007). Recent data using animal models indicate that HSP70 also regulates cardiac hypertrophy via several mechanisms (Kim et al., 2006; Kee et al., 2008). Interestingly, HSPs have been found to be a regulator of $\mathrm{NF}-\kappa \mathrm{B}$ cascade in inflammation induced by angiotensin II (Zhou et al., 2005; Chen et al., 2006). However, it is still unclear whether HSP90 is associated with NF- $\kappa B$ cascade in the modulation of cardiac cell hypertrophy induced by angiotensin II. In this study, we investigated the role of $\mathrm{HSP} 90$ on $\mathrm{NF}-\kappa \mathrm{B}$ activation pathway in angiotensin II-induced cardiac cell hypertrophy.

\section{Results}

\section{HSP90 inhibitor suppressed angiotensin II-induced cardiac cell hypertrophy}

To confirm the hypertrophic effect of angiotensin II in cardiac cells, $\left[{ }^{3} \mathrm{H}\right]$ leucine incorporation assay was examined in rat neonatal cardiac myocytes. Cardiac cells were treated with angiotensin II (0.1 $\mathrm{nM}-1 \mu \mathrm{M})$ for $24 \mathrm{~h}$. Angiotensin II increased $\left[{ }^{3} \mathrm{H}\right]$ leucine incorporation in a concentration-dependent manner in cardiac myocytes (Figure 1A). A similar result was obtained using the assessment of the ratio of total protein to DNA content (data not shown). To determine whether HSP90 modulates angiotensin II-induced cardiac hypertrophy, we primarily utilized the HSP90-specific inhibitor, geldanamycin (GA). Cardiac cells were pretreated with various concentration of GA for $2 \mathrm{~h}$ prior to stimulation of the cells with angiotensin II for $24 \mathrm{~h}$. As shown in Figure $1 \mathrm{~B}$, angiotensin II-induced $\left[{ }^{3} \mathrm{H}\right]$ leucine incorporation was inhibited by $\mathrm{GA}$ in a concentration-dependent manner. The specific marker of hypertrophy, the artrial natriuretic factor (ANF), was also visualized by immunocytochemical staining assay. GA treatment significantly decreased the ANF level in cells, while ANF was
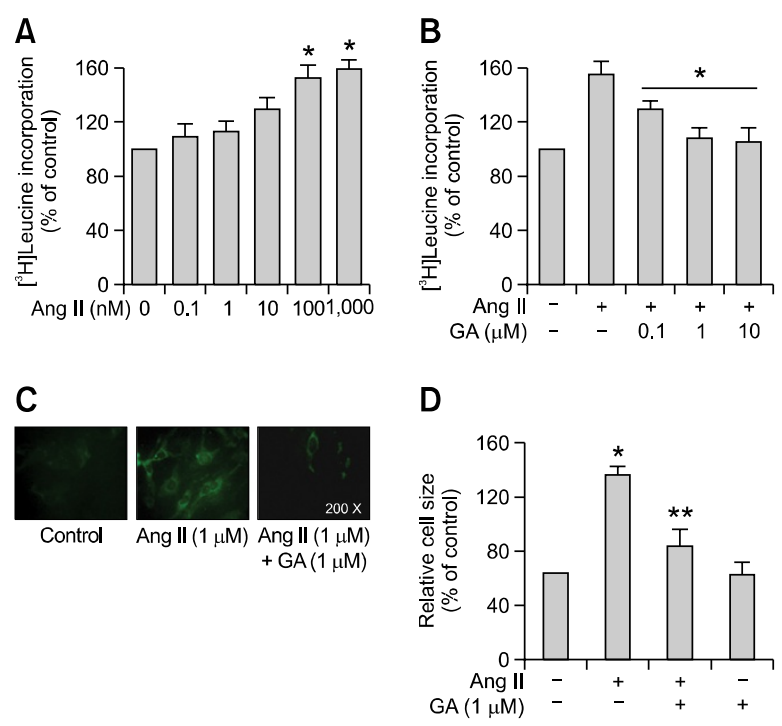

Figure 1. Effect of geldanamycin on angiotensin II-induced cellular hypertrophy in rat cardiomyocytes. (A) Cardiac cells were treated with angiotensin (Ang II) for $24 \mathrm{~h}$ with pulsed addition of $\left.{ }^{3} \mathrm{H}\right]$ leucine for the final $4 \mathrm{~h}$. At the end of labeling, cells were washed with PBS and treated with $5 \%$ trichloroacetic acid for $30 \mathrm{~min}$. An aliquot was taken to determine the incorporated radioactivity by liquid scintillation counting. ${ }^{*} P<0.01 \mathrm{com}-$ pared to control. (B) Cardiac cells were pretreated with geldanamycin (GA) for $2 \mathrm{~h}$. Then cells were stimulated with angiotensin II $(1 \mu \mathrm{M})$ for 24 $\mathrm{h}$ with pulsed addition of $\left.{ }^{3} \mathrm{H}\right]$ leucine for the final $4 \mathrm{~h} .{ }^{*} P<0.01 \mathrm{com}-$ pared to angiotensin II $(1 \mu \mathrm{M})$ alone. (C) Cardiac cells were pretreated with $\mathrm{GA}(1 \mu \mathrm{M})$ for $2 \mathrm{~h}$ prior to stimulation of the cells with angiotensin II $(1 \mu \mathrm{M})$ for $24 \mathrm{~h}$. Immunocytochemistry assay was performed using anti-atrial natriuretic factor (ANF) antibody. (D) Cardiac cells were pretreated with geldanamycin $(G A, 1 \mu \mathrm{M})$ for $2 \mathrm{~h}$. Then cells were stimulated with angiotensin II $(1 \mu \mathrm{M})$ for $24 \mathrm{~h}$. The relative cell surface area was analyzed using NIH image software. The results represent the means of three independent experiments in which 50 cells were counted in each experiment. ${ }^{*} P<0.01$ compared to control. ${ }^{* *} P<0.01$ compared to angiotensin II $(1 \mu \mathrm{M})$ alone.

detected around the nucleus in the angiotensin II-treated group compared with untreated cells (Figure 1C). Angiotensin II also increased cell size, a characteristic feature of hypertrophic response, in cardiac cells, an effect that was significantly inhibited by GA treatment (Figure 1D). The same results were observed even when GA derivative 17-(allylamino)-17-demethoxygeldanamycin (17-AAG), another HSP90 inhibitor, was used in place of GA (data not shown).

\section{Effect of HSP90 inhibitor on angiotensin II-induced NF- $\kappa$ B activation in cardiac cells}

To assess whether HSP90 regulates the $N F-\kappa B$ activation, we examined the nuclear translocation of $N F-\kappa B$ p65 subunit and $N F-\kappa B$ luciferase activity. Angiotensin II stimulated the nuclear translocation of p65 NF- $\kappa \mathrm{B}$ in cardiac cells (Figure $2 \mathrm{~A}$ ). NF- $\kappa \mathrm{B}$ luciferase activity was also enhanced 

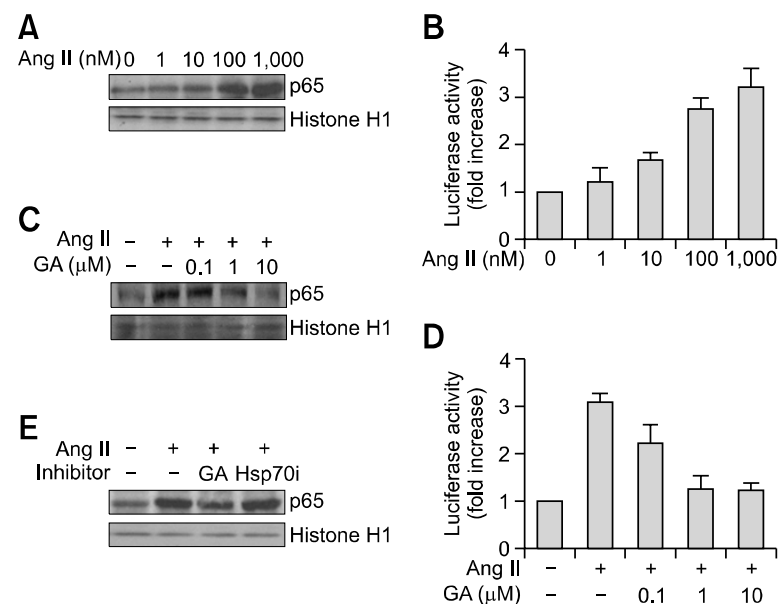

Figure 2. Effect of geldanamycin on the NF-kB activation. (A) Cardiac cells were treated with angiotensin II (Ang II) for $1 \mathrm{~h}$. Nuclear extracts were prepared and equal amounts of protein were separated by SDS-PAGE gel. The nuclear translocation of NF- $\kappa B$ was visualized by immunoblot

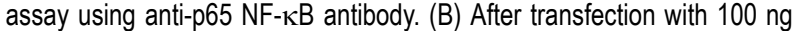
of pNF-kB/LUC luciferase vector for $24 \mathrm{~h}$, cells were treated with angiotensin II for $6 \mathrm{~h}$. Luciferase activity was determined using Luciferase Reporter Assay Kit. (C) Cardiac cells were pretreated with geldanamycin (GA) for $2 \mathrm{~h}$. Then cells were incubated with angiotensin II $(1 \mu \mathrm{M})$ for $1 \mathrm{~h}$. Equal amounts of nuclear protein were separated by SDS-PAGE gel, and nuclear translocation of NF- $\kappa B$ was detected using an anti-p65 NF- $\kappa B$ antibody. (D) After transfection with pNF-kB/LUC luciferase vector for 24 $\mathrm{h}$, cells were pretreated with $\mathrm{GA}$ for $2 \mathrm{~h}$ prior to angiotensin $\|(1 \mu \mathrm{M})$ treatment for $6 \mathrm{~h}$. Nuclear translocation of NF- $\mathrm{KB}$ was detected using an anti-p65 NF-KB antibody. (E) Cardiac cells were pretreated with GA (1 $\mu \mathrm{M})$ or HSP70 inhibitor (Hsp70i, $100 \mu \mathrm{M})$ for $2 \mathrm{~h}$. Then cells were incubated with angiotensin II $(1 \mu \mathrm{M})$ for $1 \mathrm{~h}$. Nuclear translocation of $\mathrm{NF}-\kappa \mathrm{B}$ was detected using an anti-p65 NF- $\kappa \mathrm{B}$ antibody. The results represent the means of three independent experiments.

by the addition of angiotensin II in a concentration-dependent manner (Figure 2B). However, cardiac cells treated with GA showed that nuclear translocation of p65 NF- $\kappa$ B was decreased in a concentration-dependent manner (Figure 2C). The $N F-\kappa B$ luciferase activity decreased with the same trend as the result in Figure $2 \mathrm{C}$ (Figure 2D). The

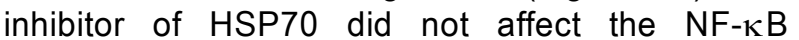
activation; more precisely, it was slightly increased by the HSP70 inhibitor (Figure 2E). These data show that HSP90 might be an important regulator of the NF- $\mathrm{B}$ pathway in angiotensin II-induced hypertrophy in cardiac cells.

\section{Effect of HSP90 inhibitor on IKK complex and stability}

In the classical NF- $\kappa \mathrm{B}$ activation pathway, the IKK complex is activated, which subsequently initiates phosphorylation of the I $\mathrm{B} \alpha$ (Luo et al., 2005). We assessed the effect of $\mathrm{GA}$ on $I_{\kappa} \mathrm{B} \alpha$ phosphorylation induced by angiotensin II in cardiac cells. As shown in the top panel of Figure $3 \mathrm{~A}$, the pretreatment of $\mathrm{GA}$ to cardiac cells inhibited
A

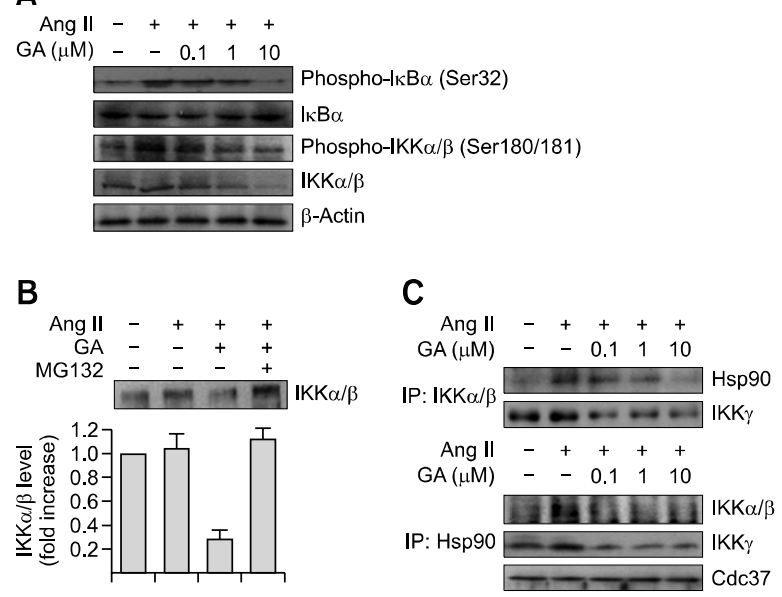

Figure 3. Effect of geldanamycin on IKK complex and stability. (A) Cardiac cells were pretreated with geldanamycin (GA) for $2 \mathrm{~h}$. Then cells were incubated with angiotensin II (Ang II, $1 \mu \mathrm{M}$ ) for $1 \mathrm{~h}$. Equal amounts of protein were separated by SDS-PAGE gel, and immunoblot analysis was performed. (B) Cardiac cells were exposed to angiotensin II (1 $\mu \mathrm{M})$ for $1 \mathrm{~h}$ with or without pretreatment with $\mathrm{GA}(1 \mu \mathrm{M})$ and/or MG132 (10 $\mu \mathrm{M})$ for $2 \mathrm{~h}$. Equal amounts of protein were separated by SDS-PAGE gel, and immunoblot analysis was performed using anti-IKK $\alpha / \beta$ antibody. Each signal was quantified by scanning densitometry and the graph shows the levels of each activity as relative value. Data are averages of three independent experiments. (C) Cardiac cells were pretreated with GA for $2 \mathrm{~h}$. Then cells were incubated with angiotensin $\|(1 \mu \mathrm{M})$ for $1 \mathrm{~h}$. Cell extracts were immunoprecipitated with anti-IKK $\alpha / \beta$ or anti-HSP90 antibodies. Immunoprecipitant samples were analyzed by immunoblot assay with anti-HSP90, anti-IKK $\alpha / \beta$, anti-IKK $\gamma$, or anti-cdc37 antibodies.

angiotensin II-induced $I \kappa B \alpha$ phosphorylation. Interestingly, in the presence of $G A$, the levels of phospho-IKK $\alpha / \beta$ and total IKK $\alpha / \beta$ decreased (Figure 3A, middle panel). However, GA did not affect IKK $\alpha / \beta$ transcription (data not shown). This result may imply that a level of IKK $\alpha / \beta$ decreased by $\mathrm{GA}$ is involved in proteasomal degradation. In fact, the protein level of $\mathrm{IKK} \alpha / \beta$ is restored with a treatment of proteasome inhibitor MG-132 (Figure $3 \mathrm{~B})$. The interaction of HSP90 with IKK complex is possibly an important factor for IKKs stability. Recent studies also have demonstrated that HSP90 is associated with IKKs (Broemer et al., 2004; Pittet et al., 2005). We examined whether the interaction of HSP90 with IKKs is altered by GA treatment in cardiac cells. When cardiac cells were stimulated with angiotensin II, HSP90 interacted with IKK $\alpha / \beta$ and IKK $\gamma$ (Figure 3C). However, as shown in Figure $3 C$, the interaction between HSP90 and IKK complex was reduced in GAtreated cardiac cells. The interaction between HSP90 and IKK $\gamma$ was also reduced when cardiac cells were treated with GA. The interaction between HSP90 and cdc37 was not changed (Figure $3 \mathrm{C})$. Immunoprecipitation with control IgG revealed no detectable interaction of IKK complex or HSP90 
A



B
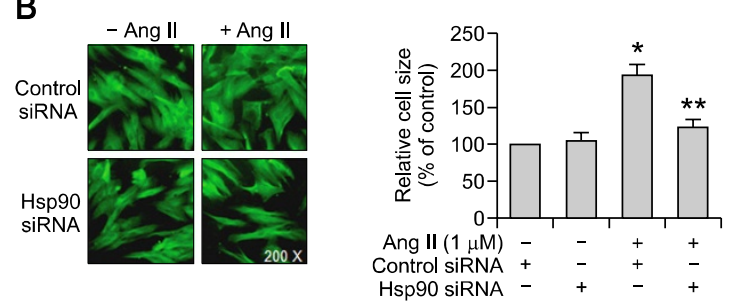

C

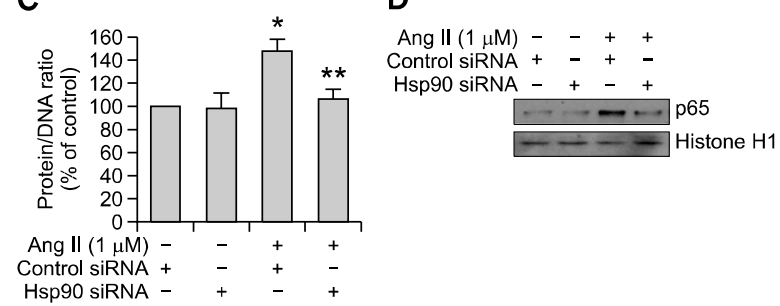

Figure 4. Effect of HSP90 knockdown on angiotensin Il-induced cellular hypertrophy in cardiac cells. (A) Cells were transfected with $30 \mathrm{nM}$ of HSP90 siRNA. After $48 \mathrm{~h}$, the levels of HSP90 $\alpha$ and HSP90 $\beta$ were analyzed with anti-HSP90 $\alpha$ and anti-HSP90 $\beta$ antibodies. (B) After $48 \mathrm{~h}$ of transfection with siRNAs, cells were treated with $1 \mu \mathrm{M}$ of angiotensin II for $24 \mathrm{~h}$. Immunocytochemistry assay was performed using anti- $\beta$-tubulin antibody. The relative cell surface area was analyzed using NIH image software. The results represent the means of three independent experiments in which 50 cells were counted in each experiment. ${ }^{*} P<0.01$ compared to control. ${ }^{* *} P<0.01$ compared to angiotensin II $(1 \mu \mathrm{M})$. (C) Total protein and DNA contents of cells were measured using BCA assay and Hoechst 33258, respectively. The results represent the means of three independent experiments. ${ }^{*} P<0.01$ compared to control. ${ }^{* *} P<$ 0.01 compared to angiotensin II $(1 \mu \mathrm{M})$. (D) After $48 \mathrm{~h}$ of transfection with siRNA, cells were treated with $1 \mu \mathrm{M}$ of angiotensin II for $1 \mathrm{~h}$. Nuclear translocation of NF- $\kappa B$ was detected using an anti-p65 NF- $\mathrm{KB}$ antibody.

(data not shown).

\section{Effect of HSP90 siRNA on angiotensin II-induced cardiac cell hypertrophy}

We confirmed the effect of HSP90 on angiotensin II-induced cardiac cell hypertrophy using gene silencing method with small interfering RNA (siRNA) targeting HSP90. Knockdown of HSP90 with siRNA was confirmed by immunoblot analysis (Figure 4A). Exposure of cells to both scrambled siRNA and HSP90 siRNAs had no effect on cell viability or cellular senescence (data not shown). Treatment of HSP90 siRNA blocked the cell size increase induced by angiotensin II (Figure 4B). A same result was also obtained using the assessment of the ratio of total protein to DNA content (Figure 4C). As shown in Figure 4D, nuclear translocation of $265 \mathrm{NF}-\kappa \mathrm{B}$ stimulated by angiotensin II was significantly decreased in the cells transfected with HSP90 siRNA compared to the scrambled control siRNA transfected-cells. These results suggest that HSP90 plays a critical role in angiotensin II-induced cardiac cell hypertrophy.

\section{Discussion}

Cellular hypertrophy is an adaptive process for synthesizing proteins without DNA replication, leading to protein accumulation (Hannan et al., 2003). Several investigations recently have implicated NF- $\kappa \mathrm{B}$ activation as a classical event of inflammation response that is critical to the cardiac hypertrophic response (Brasier et al., 2000; Purcell et al., 2001). In addition, NF- $\kappa B$ plays an important role in cardiac hypertrophy induced by angiotensin II (Li et al., 2004; Freund et al., 2005).

In this study, we have investigated the requirement of HSP90 for NF- $\mathrm{BB}$ activation in angiotensin II-induced cardiac cell hypertrophy. The study's major finding is that the HSP90 inhibitor, geldanamycin (GA), prevents angiotensin II-induced cardiac cell hypertrophy by blocking the $\mathrm{NF}-\kappa \mathrm{B}$ activation signal. Moreover, GA decreases the IKK $\alpha / \beta$ stability and blocks the interaction of HSP90 with IKK complex in response to angiotensin II. Although several examples of evidence on the roles of HSP90 in the NF- $\mathrm{BB}$ pathway have been reported recently (Arthur et al., 2007; Ammirante et al., 2008), the crosstalk between HSP90 and the NF- $\kappa B$ signaling cascade in cardiac hypertrophy induced by angiotensin II remains unclear. In the present work, accompanied by cellular hypertrophic events, angiotensin II activated the NF- $\kappa B$ signaling cascade such as IKKs activation and NF-KB nuclear translocation, which finding is consistent with previous studies. However, GA inhibited this NF- $\mathrm{BB}$ signaling cascade and hypertrophic event induced by angiotensin II in cardiac cells. GA is an HSP90specific inhibitor that binds within the ATPassociated pocket of HSP90 (Piper, 2001). HSP90 has been shown to regulate many intracellular proteins called client proteins for HSP90 (Zhao and Houry, 2007). GA abolishes the interactions between these client proteins and HSP90, lowering their stability (Piper, 2001; Sharp and Workman, 2006). In our study, as Figure $3 A$ and $B$ shows, protein levels of $1 \mathrm{KK} \alpha / \beta$ were increased in angiotensin II-treated cardiac cells, but none of their mRNA levels of IKK $\alpha / \beta$ changed (data not 
shown). However, GA significantly decreased the $\mathrm{IKK} \alpha / \beta$ levels in cells stimulated by angiotensin (Figures $3 A$ and $B$ ). As a consequence, the phosphorylation of $I_{\kappa} B \alpha$ decreased following $G A$ treatment. On the other hand, MG-132 treatment restored the protein levels of IKK $\alpha / \beta$ (Figure $3 \mathrm{~B}$ ), suggesting that $G A$ degraded $I K K \alpha / \beta$ via the ubiquitin-proteasome pathway. It is possible that HSP90 affects the IKK complexes' stability by interacting with them. Pittet et al. have shown that GA increased the IKK complex's insolubility and degradation, and that exposure to GA reduced the interaction between HSP90 and IKK $\alpha$ (Pittet et al., 2005). In the present study, HSP90 strongly interacted with the $\mathrm{IKK}$ complex in angiotensin II-treated cardiac cells (Figure 3C). However, GA treatment dramatically reduced the interaction between HSP90 and the IKK complex. These results suggest that HSP9O is directly associated with the IKK complex and that this interaction contributes to the IKKs' stabilization and activation, leading to $\mathrm{NF}-\kappa \mathrm{B}$ activation-mediated cardiac hypertrophy in response to angiotensin II. Meanwhile, the interaction between HSP90 and cdc37 did not change when cardiac cells were treated with GA (Figure 3C). Recently, Zhang et al. demonstrated that $\mathrm{GA}$ did not change the HSP90-cdc37 interaction in pancreatic cells (Zhang et al., 2008). Their study sought to identify a novel HSP90 inhibitor to disrupt the HSP90Cdc37 interaction. No GA changed the HSP90cdc37 interaction, but celastrol treatment significantly reduced the HSP90-cdc37 complex, which suggests that GA cannot disrupt the HSP90-cdc37 interaction (Zhang et al., 2008). Also, HSP90 is stably associated with the cdc37 for IKK recruitment and NF- $\kappa B$ activation (Chen et al., 2002). Thus, it is conceivable that the complex formation with HSP90-Cdc37 is a prerequisite for the IKK complex's interaction with HSP90 in angiotensin II-induced cardiac hypertrophy.

Because GA, an HSP90 inhibitor, is known to induce HSP70 expression in cardiac tissue (Kiang et al., 2006), we clarified the specific role of HSP90 in angiotensin II-induced cell hypertrophy using the siRNA-mediated HSP90 knockdown method. Knocking down endogenous HSP90 totally eliminated angiotensin II-induced cell hypertrophy and nuclear translocation of p65 NF- $\kappa \mathrm{B}$ in cardiac cells (Figure 4). Recently, HSP70 has been found to be a novel regulator of cardiac hypertrophy (Kim et al., 2006; Kee et al., 2008) and the NF- $\mathrm{B}$ pathway's activation (Zheng et al., 2008). In line with this, our results show that the HSP70 inhibitor slightly increased nuclear translocation of p65 NF- $\mathrm{B}$ (Figure 2E). Evidence also suggests that heat shock factor 1 (HSF1) known, as a transcription factor of HSP70 and HSP90, regulates cardiac hypertrophy (Sakamoto et al., 2006).

Because HSP90 also cooperates simultaneously with several cellular signaling pathways, it might affect intracellular proteins involved in cardiac hypertrophy. Angiotensin II also activates many cellular signaling pathways, such as $\mathrm{NADPH}$ oxidase, MAP kinases, protein phosphatase calcineurin, and calcium channel, that are implicated in cardiac hypertrophy (Schluter and Wenzel, 2008; Do et al., 2009). Cardiac hypertrophy is likely the result of cooperation of several signaling pathways, rather than a single pathway; and among several signaling pathways, the $N F-\kappa B$ signaling cascade plays a pivotal role in angiotensin II-induced cardiac hypertrophy (Freund et al., 2005; Kawano et al., 2005). Taken together, these results suggest that different HSPs, including HSP90, regulate signaling pathways involved in cardiac hypertrophy through their different distinct roles. Although experimental evidence on each HSP's biochemical roles has accumulated, it remains unclear how crosstalk between HSPs and the signaling network is regulated during cardiac hypertrophy under physiologic and pathologic conditions. Future studies need to clarify the signaling network between the $N F-\kappa B$ pathway and other cellular signal factors and to elucidate the HSPs roles' in this network stimulated by angiotensin II, leading to cardiac hypertrophic processes.

Numerous studies have shown that the direct effect of angiotensin II on cardiac hypertrophy is mediated mainly via the angiotensin II type 1 receptor (AT1R) (Zhu et al., 2003). An important link between angiotensin II and cardiac hypertrophy is $N F-\kappa B$, activated mainly via AT1R by angiotensin II stimulation (Kalra et al., 2002). On the other hand, many reports on the angiotensin II type 2 receptor's (AT2R) ambiguous role have emerged stating that AT2R either inhibits or stimulates cardiac hypertrophy (Zhu et al., 2003). Moreover, it remains unclear whether AT2R modulates NF- $\kappa$ B activation mediated by AT1R with angiotensin II. How, then, does HSP90, as a molecular chaperone involved in other proteins' folding, stability, and maturation, actively regulate angiotensin II-induced NF- $\mathrm{B}$ activation? Although HSP90 typically is described as protein-folding machinery, it also is implicated in the regulation of cellular signaling and the cell cycle progression (Brown et al., 2007). HSP90 also plays a key role in inflammatory and immune responses such as $N F-\kappa B$ and Janus kinase (JAK)-signal transducer and activators of transcription (STAT) pathway 
(Madrigal-Matute et al., 2010). Some studies indicate that angiotensin II increases the HSP90 level, inducing inflammatory and oxidative stress in vascular smooth muscle cells and brain microvessels from spontaneously hypertensive rats ( $\mathrm{Li}$ et al., 2005; Zhou et al., 2005), suggesting that HSP90 actively regulates angiotensin II-responsive signaling pathways. However, our results show that, HSP27 and HSP70 accumulated significantly after the cardiac cells had been incubated with angiotensin II for $24 \mathrm{~h}$, but they had little or nothing to do with the HSP90 level (data not shown). It thus seems that angiotensin II-induced cellular hypertrophy is regulated by a change in the status of HSP90's interactions with other proteins, rather than its expression, at least in cardiac cells. Indeed, as Figure $3 \mathrm{C}$ shows, interaction between HSP90 and $\mid \mathrm{KK} \alpha / \beta$ increased markedly in angiotensin II-treated cells. Thus, it is tempting to assume that, under normal conditions, HSP90 remains in release from other proteins, but, when cells are stimulated with angiotensin II, HSP90 might associate with other target proteins such as IKK $\alpha / \beta$, leading to cardiac hypertrophy.

Recently, HSP90 has become a new drug target for several diseases (Solit and Chiosis, 2008). In our results, HSP90's interaction with the IKK complex might be necessary for IKK's stability and activity, thereby activating the NF- $\kappa B$ pathway in angiotensin II-induced cardiac hypertrophy. So, HSP90 modulators might be potential candidates for new therapeutics to treat cardiac hypertrophy. Although some evidence has suggested HSPs' roles in the NF- $\mathrm{KB}$ cascade, our data provide the first proposal on the crosstalk between HSP90 and the IKK complex-NF- $\kappa B$ cascade in the modulation of cardiac cell hypertrophy induced by angiotensin II.

\section{Methods}

\section{Materials}

Angiotensin II was purchased from Sigma (St. Louis, MO).

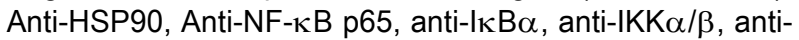
cdc37, and anti-histone $\mathrm{H} 1$ antibodies were purchased from Santa Cruz Biotechnology (Santa Cruz, CA). Antiphospho-I $\mathrm{B} \alpha$ (ser32) and anti-phospho-IKK $\alpha / \beta$ (Ser180/ 181) antibodies were purchased from Cell Signaling (Beverly, MA). Anti-HSP $\alpha$ and anti-HSP $\beta$ antibodies were purchased from Assay Designs (Ann Arbor, MI). Horseradish peroxidase-conjugated secondary antibodies and enhanced chemiluminescence detection system were obtained from Santa Cruz Biotechnology, and Amersham Biosciences (Uppsala, Sweden), respectively. Geldanamycin, 17-Allylaminogeldanamycin (17-AAG) and KNK437 (Hsp70 inhibitor) were purchased from Calbiochem (San
Diego, CA).

\section{Cell culture}

Rat neonatal ventricular cardiac myocytes were prepared as described previously with minor modifications (De Windt et al., 1997). All animal procedures were carried out according to a protocol approved by the Yonsei University Animal Care Committee. Heart from neonatal (1-2 days old) Sprague-Dawley rat was excised, and washed with phosphate-buffered saline (PBS) and minced. The minced myocardial tissues were incubated with $0.1 \%$ collagenase type II (Gibco, Grand Island, NY) with PBS. After digestion for $10 \mathrm{~min}$, the cells were collected by centrifugation and resuspended in $\alpha$-MEM containing $10 \%$ fetal bovine serum (FBS) and $100 \mathrm{U} / \mathrm{ml}$ penicillin/ streptomycin. Cells were pre-plated for $1 \mathrm{~h}$ at $37^{\circ} \mathrm{C}$ in $\mathrm{CO}_{2}$ incubator to allow removal of fibroblasts. Unattached cardiac myocytes were plated in gelatin coated dishes and incubated for $24 \mathrm{~h}$.

\section{Measurement of $\left[{ }^{3} \mathrm{H}\right]$ leucine incorporation}

$\left[{ }^{3} \mathrm{H}\right]$ Leucine incorporation was measured as described previously (Nozato et al., 2000). Cells were grown in 24-well plates with serum-free medium for $24 \mathrm{~h}$. Cells were then treated with angiotensin II for $24 \mathrm{~h}$ after pretreatment with or without inhibitor. The cells were pulsed with 1 $\mu \mathrm{Ci} / \mathrm{ml}$ of $\left[{ }^{3} \mathrm{H}\right]$ leucine (Amersham Biosciences) during the last $4 \mathrm{~h}$ before harvest. After being washed with PBS, cells were treated with $5 \%$ trichloroacetic acid for $30 \mathrm{~min}$ and then washed with PBS. Finally, cells were solubilized in $500 \mu$ of $1 \mathrm{~N} \mathrm{NaOH}$. After neutralization with $0.5 \mathrm{~N} \mathrm{HCl}$, an aliquot was taken to determine the incorporated radioactivity using liquid scintillation counter, Beckman LS 3801 (Beckman, Fullerton, CA).

\section{Measurement of protein and DNA content}

The cells were washed with ice-cold PBS and lysed in 0.3 $\mathrm{M} \mathrm{NaOH}$. For the protein content analysis, the cell extract was assayed by bicinchoninic acid reagent system (BCA assay kit, Sigma). For measurement of DNA concentration, the cell extract was treated with $\mathrm{NaOH}$ and then neutralized. Samples were incubated with $1.5 \mu \mathrm{M}$ of Hoechst 33258 for $15 \mathrm{~min}$ in a darkroom. The Hoechst 33258-labeled DNA was quantified using spectrofluoremeter Victor 3 (Perkin-Elmer, Waltham, MA) with excitation at $355 \mathrm{~nm}$ and the emission at $460 \mathrm{~nm}$.

\section{Measurement of cell surface area}

In the experiment of cell surface area measurement, cells were incubated with FITC-conjugated $\beta$-tubulin antibody (Sigma). The cells were photographed, and the surface area was analyzed using NIH image software.

\section{Immunocytochemistry}

Cells were plated in the 4-well slide chamber (Nalge Nunc, Rochester, NY) and grown with serum-free medium for 24 h. Cells were fixed with $4 \%$ paraformaldehyde, and then 
after the washing with PBS containing $0.2 \%$ NP-40, cells were blocked with $10 \%$ goat serum-containing PBS and incubated with anti-atrial natriuretic factor antibody (Peninsula Labs, San Carlos, CA). Cells were incubated with FITC-conjugated secondary antibody. Photographs of cells were taken using immunofluorescence microscopy (Olympus, Melville, NY).

\section{NF- $\kappa$ B luciferase activity assay}

Cells were transfected with $\mathrm{NF}-\kappa \mathrm{B} / \mathrm{luciferase}$ reporter vector (pNF-kB/LUC, BD Biosciences, San Jose, CA). The pcDNA3.1/lacZ was also co-transfected to cells as an internal control of transfection efficiency detection. After 3 $\mathrm{h}$, the cells were grown overnight in fresh media. And then cells were starved and exposed to angiotensin II with or without inhibitor. The luciferase activity was determined using Luciferase Reporter Assay Kit (BD Biosciences). The activity of the NF- $\kappa B$ reporter luciferase was standardized to that of $\beta$-galactosidase activity.

\section{Nuclear protein extraction}

Nuclear extracts were prepared as described previously (Kang et al., 2001). Briefly, cells were washed, and then scraped with PBS, and centrifuged at $3,000 \mathrm{rpm}$ at $4^{\circ} \mathrm{C}$. The pellets were suspended in $10 \mathrm{mM}$ Tris $(\mathrm{pH} 8.0)$ with $1.5 \mathrm{mM} \mathrm{MgCl} 2,1 \mathrm{mM}$ DTT, $0.1 \% \mathrm{NP}-40$ and incubated on ice for $15 \mathrm{~min}$. Nuclei were separated from cytosol by centrifugation at $12,000 \mathrm{rpm}$ at $4^{\circ} \mathrm{C}$ for $15 \mathrm{~min}$. The cytosolic supernatants were removed, and the precipitated pellets were suspended in $10 \mathrm{mM}$ Tris $(\mathrm{pH} \mathrm{8.0)}$ containing $100 \mathrm{mM} \mathrm{NaCl}$ and stored on ice for $30 \mathrm{~min}$. After agitation for $30 \mathrm{~min}$ at $4^{\circ} \mathrm{C}$, the lysate was centrifuged at $12,000 \mathrm{rpm}$ at $4^{\circ} \mathrm{C}$, and the supernatant was collected. The nuclear protein concentration was determined using Bradford protein assay kit (Bio-Rad, Hercules, CA).

\section{SDS-PAGE and immunoblot analysis}

Cells lysate was centrifuged at $12,000 \mathrm{~g}$ for $20 \mathrm{~min}$ at $4^{\circ} \mathrm{C}$. Protein samples were separated in a $12 \%$ SDSpolyacrylamide gel and electrotransferred to polyvinylidene difluoride membranes. The membranes were washed with tris-buffered saline (TBS) and blocked by incubation with $5 \%$ nonfat dry milk in TBS for $1 \mathrm{~h}$. The membranes were incubated with specific primary antibodies for $1 \mathrm{~h}$. After washing, membranes were incubated with horseradish peroxidase-conjugated secondary antibody and then detected with enhanced chemiluminescence detection solution.

\section{Immunoprecipitation assay}

Cells were washed with PBS and lysed in a lysis buffer (Cell signaling). Cell lysates were incubated with antibody for $2 \mathrm{~h}$ at $4^{\circ} \mathrm{C}$ on a rotating plate. Precipitation was carried out with protein $A / G$ agarose plus (Santa Cruz Biotechnology). Samples were separated by SDS-PAGE and subjected to immunoblot analysis.

\section{HSP90 siRNA transfection}

Rat HSP90 siRNA oligonucleotides were designed and synthesized from Genolution Pharmaceuticals (Seoul, Korea) as follows; HSP90 $\alpha$ siRNA sequences, 5'-GCAGAAAUUGCCCAGUUAA-3', 5'-GCUGCACAUUAAUCUCAUU-3' and 5'-GUGGAUACUGGCAUUGGAA-3'; HSP90 $\beta$ siRNA sequences, 5'-GAUCCUCACCUCA AAGAA-3', 5'GAAGGAGAUCAGUGAUGAU-3' and 5'-GGAUGACAGCGGCAAAGAU-3'. Cells were transfected with the pool of six HSP90 siRNAs (5 $\mathrm{nM}$ each) using Lipofectamine RNAiMAX (Invitrogen, Carlsbad, CA, USA). After 48h of transfection, the levels of HSP90 $\alpha$ and HSP90 $\beta$ were analyzed with anti-HSP90 $\alpha$ and anti-HSP90 $\beta$ antibodies. A scrambled siRNA-A (Santa Cruz Biotechnology) was used as control.

\section{Statistical analysis}

Data are expressed as means \pm S.E. Statistical comparisons were performed by one-way analysis of variance and Student's $t$-test. Differences were considered significant at $P<0.05$.

\section{Acknowledgements}

This study is supported by the Ministry of Education, Science and Technology (MEST), the Ministry of Knowledge Economy (MKE) and the Ministry of Labor (MOLAB) through the fostering project of the Lab of Excellency, and this study was also supported by Basic Science Research Program through the National Research Foundation of Korea (NRF) funded by the Ministry of Education, Science and Technology (Grant No. 20090075206). This study was also supported by a grant of the Korea Healthcare Technology R\&D Project, Ministry for Health, Welfare \& Family Affairs, Republic of Korea (A085136). This study was also supported by a faculty research grant of Yonsei University College of Medicine for 2009 (8-2009-0190).

\section{References}

Ammirante M, Rosati A, Gentilella A, Festa M, Petrella A, Marzullo L, Pascale M, Belisario MA, Leone A, Turco MC. The activity of hsp90 alpha promoter is regulated by NF-kappa B transcription factors. Oncogene 2008;27:1175-8

Arthur JC, Lich JD, Aziz RK, Kotb M, Ting JP. Heat shock protein 90 associates with monarch-1 and regulates its ability to promote degradation of NF-kappaB-inducing kinase. J Immunol 2007;179:6291-6

Brasier AR, Jamaluddin M, Han Y, Patterson C, Runge MS. Angiotensin II induces gene transcription through celltype-dependent effects on the nuclear factor-kappaB (NF-kappaB) transcription factor. Mol Cell Biochem 2000; 212:155-69

Broemer M, Krappmann D, Scheidereit C. Requirement of Hsp90 activity for lkappaB kinase (IKK) biosynthesis and for constitutive and inducible IKK and NF-kappaB activation. 


\section{Oncogene 2004;23:5378-86}

Brown MA, Zhu L, Schmidt C, Tucker PW. Hsp90-from signal transduction to cell transformation. Biochem Biophys Res Commun 2007;363:241-6

Chen G, Cao P, Goeddel DV. TNF-induced recruitment and activation of the IKK complex require Cdc37 and Hsp90. Mol Cell 2002;9:401-10

Chen Y, Currie RW. Small interfering RNA knocks down heat shock factor-1 (HSF-1) and exacerbates pro-inflammatory activation of NF-kappaB and AP-1 in vascular smooth muscle cells. Cardiovasc Res 2006;69:66-75

De Windt LJ, Willemsen PH, Pöpping S, Van der Vusse GJ, Reneman RS, Van Bilsen M. Cloning and cellular distribution of a group II phospholipase A2 expressed in the heart. J Mol Cell Cardiol 1997;29:2095-106

Do KH, Kim MS, Kim JH, Rhim BY, Lee WS, Kim CD, Bae SS. Angiotensin Il-induced aortic ring constriction is mediated by phosphatidylinositol 3-kinase/L-type calcium channel signaling pathway. Exp Mol Med 2009;41:569-76

Freund C, Schmidt-Ullrich R, Baurand A, Dunger S, Schneider W, Loser P, El-Jamali A, Dietz R, Scheidereit C, Bergmann MW. Requirement of nuclear factor-kappaB in angiotensin II- and isoproterenol-induced cardiac hypertrophy in vivo. Circulation 2005;111:2319-25

Frey N, Olson EN. Cardiac hypertrophy: the good, the bad, and the ugly. Annu Rev Physiol 2003;65:45-79

Hannan RD, Jenkins A, Jenkins AK, Brandenburger Y. Cardiac hypertrophy: a matter of translation. Clin Exp Pharmacol Physiol 2003;30:517-27

Heineke J, Molkentin JD. Regulation of cardiac hypertrophy by intracellular signalling pathways. Nat Rev Mol Cell Biol 2006;7:589-600

Kalra D, Sivasubramanian N, Mann DL. Angiotensin II induces tumor necrosis factor biosynthesis in the adult mammalian heart through a protein kinase C-dependent pathway. Circulation 2002;105:2198-2205

Kang KH, Lee KH, Kim MY, Choi KH. Caspase-3-mediated cleavage of the NF-kappa B subunit p65 at the $\mathrm{NH} 2$ terminus potentiates naphthoquinone analog-induced apoptosis. J Biol Chem 2001;276:24638-44

Kawano F, Matsuoka Y, Oke Y, Higo Y, Terada M, Wang XD, Nakai N, Fukuda H, Imajoh-Ohmi S, Ohira Y. Role(s) of nucleoli and phosphorylation of ribosomal protein $\mathrm{S} 6$ and/or HSP27 in the regulation of muscle mass. Am J Physiol Cell Physiol 2007;293:C35-44

Kawano S, Kubota T, Monden Y, Kawamura N, Tsutsui H, Takeshita A, Sunagawa K. Blockade of NF-kappaB ameliorates myocardial hypertrophy in response to chronic infusion of angiotensin II. Cardiovasc Res 2005;67:689-98

Kee HJ, Eom GH, Joung H, Shin S, Kim JR, Cho YK, Choe $\mathrm{N}$, Sim BW, Jo D, Jeong MH, Kim KK, Seo JS, Kook H. Activation of histone deacetylase 2 by inducible heat shock protein 70 in cardiac hypertrophy. Circ Res 2008;103: 1259-69

Kiang JG, Bowman PD, Lu X, Li Y, Ding XZ, Zhao B, Juang
YT, Atkins JL, Tsokos GC. Geldanamycin prevents hemorrhage-induced ATP loss by overexpressing inducible HSP70 and activating pyruvate dehydrogenase. Am J Physiol Gastrointest Liver Physiol 2006;291:G117-27

Kim S, Iwao H. Molecular and cellular mechanisms of angiotensin II-mediated cardiovascular and renal diseases. Pharmacol Rev 2000;52:11-34

Kim YK, Suarez J, Hu Y, McDonough PM, Boer C, Dix DJ, Dillmann WH. Deletion of the inducible 70-kDa heat shock protein genes in mice impairs cardiac contractile function and calcium handling associated with hypertrophy. Circulation 2006;113:2589-97

Li PG, Xu JW, Ikeda K, Kobayakawa A, Kayano Y, Mitani T, Ikami T, Yamori Y. Caffeic acid inhibits vascular smooth muscle cell proliferation induced by angiotensin II in stroke-prone spontaneously hypertensive rats. Hypertens Res 2005;28:369-77

Li Y, Ha T, Gao X, Kelley J, Williams DL, Browder IW, Kao RL, Li C. NF-kappaB activation is required for the development of cardiac hypertrophy in vivo. Am J Physiol Heart Circ Physiol 2004;287:H1712-20

Luo JL, Kamata H, Karin M. IKK/NF-kappaB signaling: balancing life and death-a new approach to cancer therapy. J Clin Invest 2005;115:2625-32

Madrigal-Matute J, Lopez-Franco O, Blanco-Colio LM, Munoz-García B, Ramos-Mozo P, Ortega L, Egido J, Martin-Ventura JL. Heat shock protein 90 inhibitors attenuate inflammatory responses in atherosclerosis. Cardiovasc Res 2010;86:330-7

Marian AJ, Roberts R. Recent advances in the molecular genetics of hypertrophic cardiomyopathy. Circulation 1995; 92:1336-47

Nozato T, Ito H, Tamamori M, Adachi S, Abe S, Marumo F, Hiroe M. G1 cyclins are involved in the mechanism of cardiac myocyte hypertrophy induced by angiotensin II. Jpn Circ J 2000;64:595-601

Pereira SG, Oakley F. Nuclear factor-kappaB1: regulation and function. Int J Biochem Cell Biol 2008;40:1425-30

Piper PW. The Hsp90 chaperone as a promising drug target. Curr Opin Investig Drugs 2001;2:1606-10

Pittet JF, Lee H, Pespeni M, O'Mahony A, Roux J, Welch WJ. Stress-induced inhibition of the NF-kappaB signaling pathway results from the insolubilization of the lkappaB kinase complex following its dissociation from heat shock protein 90. J Immunol 2005;174:384-94

Purcell NH, Tang G, Yu C, Mercurio F, DiDonato JA, Lin A. Activation of NF-kappa B is required for hypertrophic growth of primary rat neonatal ventricular cardiomyocytes. Proc Natl Acad Sci USA 2001;98:6668-73

Railson JE, Lawrence K, Buddle JC, Pennica D, Latchman DS. Heat shock protein- 56 is induced by cardiotrophin- 1 and mediates its hypertrophic effect. J Mol Cell Cardiol 2001; 33:1209-21

Sakamoto M, Minamino T, Toko H, Kayama Y, Zou Y, Sano M, Takaki E, Aoyagi T, Tojo K, Tajima N, Nakai A, Aburatani 
$\mathrm{H}$, Komuro I. Upregulation of heat shock transcription factor 1 plays a critical role in adaptive cardiac hypertrophy. Circ Res 2006;99:1411-8

Schluter KD, Wenzel S. Angiotensin II: a hormone involved in and contributing to pro-hypertrophic cardiac networks and target of anti-hypertrophic cross-talks. Pharmacol Ther 2008;119:311-25

Sharp S, Workman P. Inhibitors of the HSP90 molecular chaperone: current status. Adv Cancer Res 2006;95:323-48

Solit DB, Chiosis G. Development and application of Hsp90 inhibitors. Drug Discov Today 2008;13:38-43

Zhang T, Hamza A, Cao X, Wang B, Yu S, Zhan CG, Sun D. A novel Hsp90 inhibitor to disrupt Hsp90/Cdc37 complex against pancreatic cancer cells. Mol Cancer Ther 2008; 7:162-70
Zhao R, Houry WA. Molecular interaction network of the Hsp90 chaperone system. Adv Exp Med Biol 2007;594: 27-36

Zheng Z, Kim JY, Ma H, Lee JE, Yenari MA. Anti-inflammatory effects of the $70 \mathrm{kDa}$ heat shock protein in experimental stroke. J Cereb Blood Flow Metab 2008;28:53-63

Zhou J, Ando H, Macova M, Dou J, Saavedra JM. Angiotensin II AT1 receptor blockade abolishes brain microvascular inflammation and heat shock protein responses in hypertensive rats. J Cereb Blood Flow Metab 2005;25:878-86

Zhu YC, Zhu YZ, Lu N, Wang MJ, Wang YX, Yao T. Role of angiotensin AT1 and AT2 receptors in cardiac hypertrophy and cardiac remodelling. Clin Exp Pharmacol Physiol 2003;30:911-8 